\title{
Sistem Pendukung Keputusan Penerimaan Bantuan Sosial UMKM Menggunakan Metode TOPSIS
}

\author{
Dewi Yurika ${ }^{1}$, Widia Ningsih ${ }^{2}$, Soeb Aripin ${ }^{3 *}$ \\ Program Studi Teknik Informatika, Fakultas Ilmu Komputer dan Teknologi Informasi, Universitas Budi Darma, \\ Jalan Sisingamanganraja No. 338, Medan, Sumatera Utara, Indonesia \\ Email: ${ }^{1}$ dewiyurikaa@gmail.com, ${ }^{2}$ widianingsiie@gmail.com, ${ }^{3}$ suefarifin@gamail.com
}

\begin{abstract}
Abstrak-Usaha mikro kecil menengah (UMKM) adalah usaha produktif milik perorangan atau badan usaha perorangan yang memenuhi kriteria usaha mikro kecil sebagaimana diatur dalam Undang-Undang. Pemberian bantuan modal usaha ini dilakukan oleh lembaga keungan bank untuk para pengusaha mikro kecil menengah, jadi pelaku usaha kecil memanfaatkan kesempatan ini untuk tempat mendapatkan modal. Karena adanya usaha bantuan seperti ini maka banyak pelaku usaha yang terbantu, terutama dikondisi pandemi covid-19 seperti ini. Semakin banyaknya para pelaku usaha yang ingin mengajukan pinjaman terhadap pihak bank, hal ini akan menyulitkan pihak bank untuk menyaring dan menentukan pelaku usaha mana yang memenuhi persyaratan dari mereka dan layak untuk diberikan bantuan modal usaha. Oleh sebab itu dibutuhkan Sistem Pendukung Keputusan (SPK) dengan metode Technique for Order Preference by Similarity to Ideal Solution (TOPSIS) yang akan memberikan alternatif yang terbaik dan sesuai kriteria yang ada. Penerapan TOPSIS akan memudahkan pihak Bank Negara Indonesia dalam menyeleksi dan memutuskan memberikan pemberian bantuan dana pada pihak yang tepat. Metode TOPSIS merupakan metode yang menggunakan prinsip bahwa alternatif yang terpilih harus mempunyai jarak terdekat dari solusi ideal positif dan terjauh dari solusi ideal negatif. Hasil yang didapat dari penelitian ini diperoleh hasil dengan 8 pihak usaha yang berhak mendapat bantuan dan 12 orang yang tidak berhak mendapatkan bantuan.
\end{abstract}

Kata Kunci: SPK; Bansos; Usaha Mikro Kecil Menengah; UMKM; TOPSIS.

Abstract-Micro, small and medium enterprises (MSMEs) are productive businesses owned by individuals or individual business entities that meet the criteria for micro and small businesses as stipulated in the Act. The provision of business capital assistance is carried out by bank financial institutions for micro, small and medium entrepreneurs, so small business actors take advantage of this opportunity as a place to get capital. Because of this kind of assistance effort, many business actors have been helped, especially in this COVID-19 pandemic. The more business actors who want to apply for loans from the bank, this will make it difficult for the bank to filter and determine which business actors meet their requirements and are eligible for business capital assistance. Therefore, a Decision Support System (DSS) is needed with the Technique for Order Preference by Similarity to Ideal Solution (TOPSIS) method which will provide the best alternative and according to the existing criteria. The application of TOPSIS will make it easier for Bank Negara Indonesia to select and decide to provide financial assistance to the right party. The TOPSIS method is a method that uses the principle that the chosen alternative must have the closest distance from the positive ideal solution and the farthest from the negative ideal solution. The results obtained from this study obtained results with 8 business parties who are entitled to assistance and 12 people who are not entitled to assistance.

Keywords: DSS; Social Assistance; Micro, Small and Medium Enterprises; MSMEs; TOPSIS.

\section{PENDAHULUAN}

Usaha Mikro Kecil Menengah (UMKM) merupakan kegiatan usaha berskala kecil yang mendorong pergerakan pembangunan dan perekonomian Indonesia. Sebuah usaha atau bisnis dapat disebut sebagai UMKM jika memenuhi kriteria usaha mikro. Menurut peraturan perundang-undangan Nomor 20 tahun 2008, UMKM dibedakan berdasarkan masing-masing jenis usaha, yaitu usaha mikro, kecil, dan menengah. Tentunya untuk setiap pelaku usaha yang mendapat bantuan uang tunai tersebut harus memenuhi kriteria yang sudah ditentukan oleh pemerintah misalnya, Warga Negara Indonesia (WNI), memiliki KTP elektronik, memiliki usaha mikro yang dibuktikan dengan surat usulan calon penerima BPUM dari pengusul BPUM beserta lampirannya yang merupakan satu kesatuannya, bukan ASN, anggota TNI/Polri, Pegawai BUMN atau BUMD.

Disituasi saat ini banyak negara mengalami dampak dari virus Covid-19 termasuk Indonesia, yang mengakibatkan penurunan pendapatan ekonomi, meningkatnya angka pengangguran, dan ada juga kasus kematian yang semakin merajalela. Upaya pemerintah memberikan bantuan sosial melalui usaha kecil menengah (UMKM) untuk mendukung pemulihan ekonomi bagi pelaku usaha kecil yang mengalami penurunan pendapatan akibat dampak virus Covid-19. Namun proses dalam menentukan dan menyaring pelaku usaha mana yang memenuhi persyaratan dan layak untuk diberikan bantuan modal usaha tidaklah mudah. Pihak Bank harus teliti dalam memilih pihak usaha yang memenuhi kriteria dari pemerintah. Karena banyak faktor pendukung untuk menilai pihak usaha mana yang berhak menerima bantuan usaha mikro kecil menegah (UMKM). Sehingga dibutuhkan sebuah alternatif dalam penyelesaian masalah pemilihan pihak usaha yang berhak menerima bantuan UMKM ini, banyak metode alternatif yang bisa digunakan seperti metode WASPAS, 
WP, SAW, MOORA. Dari metode-metode yang ada, pada penelitian ini digunakan metode TOPSIS dikarenakan metode ini sering dipakai dalam pembuatan sistem pendukung keputusan..

Technique for Order Preference by Similarity to Ideal Solution (TOPSIS) Merupakan metode yang akan merangking alternatif berdasarkan prioritas nilai kedekatan relatif suatu alternatif terhadap suatu solusi ideal positif. Alternatif-alternatif yang telah dirangking kemudian dijadikan sebagai referensi bagi pengambil keputusan[1]. Penerapan metode TOPSIS dalam pemberian bantuan ini merupakan kerangka kerja untuk membuat keputusan yang efektif atas masalah yang kompleks yang dihadapi saat ini dalam pengambilan keputusan sehingga dengan menyederhanakan dan mempercepat proses pengambilan keputusan dapat memecahkan masalah menjadi bagian-bagiannya agar hasil yang diperoleh dapat membantu menentukan siapa saja yang berhak yang mendapatkan bantuan modal usaha berdasarkan perankingan yang jelas[2].

Beberapa penelitian sebelumnya yang menggunakan metode Technique for Order Preference by Similarity to Ideal Solution (TOPSIS) dapat memperoleh suatu keputusan yang mampu meminimumkan serta memperoleh hasil yang lebih akurat, diantaranya penelitian tentang Pemberian Bantuan Siswa Miskin Di SD Negeri Sukamenak Kota Tasikmalaya dengan hasil penelitian yaitu diharapkan adanya pengembangan terhadap program aplikasi ini, untuk meningkatkan efisiensi kegunaannya dan melengkapi kekurangankekurangan yang ada[3]. Penelitian lain tentang pemberian bantuan data untuk usaha kecil menengah (UKM), dan hasil penelitiannya didapat penerima bantuan dana yaitu A3 dengan nilai preferensi sebesar 96,67[4]. Penelitian lainnya tentang Seleksi Penerima Bantuan Sosial Warga Masyarakat Terdampak COVID-19 hasil dari penelitian bahwa warga masyarakat terdampak Covid-19 yang sangat layak untuk mendapatkan bantuan dana sosial dengan penilaian akhir di atas 0,66 dengan rekomendasi sangat layak[5]. Ada penelitian tentang Penentuan Prioritas Bantuan Usaha Kecil dan Menengah Di Kota Tegal dengan hasil penelitian adalah sebesar 3,44 dari skala 4 atau hasilnya sebesar $86,11 \%$ menyatakan setuju dengan sistem yang telah dibuat[6].

Berdasarkan uraian di atas maka penulis tertarik untuk melakukan penelitian mengenai Penerimaan Bansos UMKM menggunakan metode Technique for Order Preference by Similarity to Ideal Solution (TOPSIS) dengan melakukan seleksi berkas, namun proses seleksi ini memiliki kelemahan dikarenakan kriteria atau preferensi yang digunakan tidak begitu jelas. Jika kriteria telah terpenuhi maka calon penerima bantuan tepat sasaran untuk menerima bantuan sosial.

\section{METODOLOGI PENELITIAN}

\subsection{Tahapan Penelitian}

Dalam melakukan penelitian ini, penulis melakukan beberapa tahapan-tahapan. Metode mengumpulkan data yang dipakai agar mendapatkan data yang sangatdiperlukan penulis yaitu sebagai berikut:

1. Tahapan Analisa, di dalam tahap ini penulis mengumpulkan data orang yang akan mendapatkan bantuan sosial.

2. Tahapan Studi Kelayakan, di dalam tahap ini memiliki tujuan agar mengetahui apakah sistem yang baru bisa realistis dalam permasalahan waktu, biaya, serta mengetahui perbedaan dengan sistem yang lama.

3. Tahapan Penggunaan Metode TOPSIS, pada tahap ini penulis akan menggunakan metode TOPSIS dalam menyeleksi pihak usaha.

4. Tahapan Penetapan Hasil, di dalam tahap ini pihak usaha yang terpilih akan mendapatkan bantuan sosial UMKM.
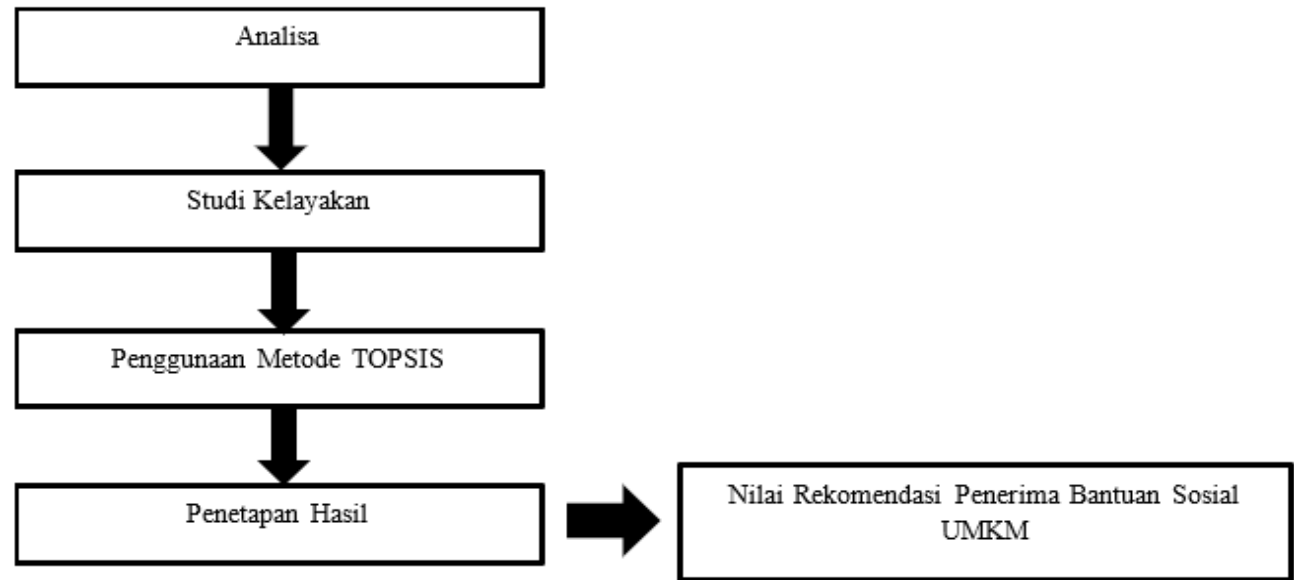

Gambar 1. Tahapan Penelitian 


\subsection{Bantuan Sosial (Bansos)}

Bantuan sosial adalah pemberian bantuan berupa uang/barang dari pemda kepada individu, keluarga, kelompok dan/atau masyarakat yang sifatnya tidak secara terus menerus dan selektif yang bertujuan untuk melindungi dari kemungkinan terjadinya resiko social [7]. Bantuan sosial sangat penting bagi pelaku usaha yang sedang kesulitan dalam ekonomi karena dapat membantu untuk modal usaha mereka.

\subsection{Sistem Pendukung Keputusan}

Sistem Pendukung Keputusan (SPK) digunakan sebagai alat bantu bagi para pengambil keputusan untuk memperluas kapabilitas para pengambil keputusan, namun tidak untuk menggantikan penilaian para pengambil keputusan Pada prinsipnya keberadaan SPK, hanya sebagai sistem pendukung untuk pengambilan keputusan, bukan menggantikannya [8]. Sistem Pendukung Keputusan juga merupakan sistem informasi berbasis komputer untuk manajemen pengambilan keputusan yang menangani masalah-masalah semistruktur [3].

\subsection{Metode Technique for Order Preference by Similarityto Ideal Solution (TOPSIS)}

Menurut Sachdeva (2009) Technique for Order Preference by Similarity to Ideal Solution (TOPSIS) Merupakan metode yang akan merangking alternatif berdasarkan prioritas nilai kedekatan relatif suatu alternatif terhadap suatu solusi ideal positif. Alternatif-alternatif yang telah dirangking kemudian dijadikan sebagai referensi bagi pengambil keputusan [1]. TOPSIS telah digunakan dalam banyak aplikasi termasuk keputusan investasi keuangan, perbandingan performansi dari perusahaan, perbandingan dalam suatu industri khusus, pemilihan sistem operasi, evaluasi pelanggan, dan perancangan robot [9].

Berikut ini adalah langkah dari metode TOPSIS:

1. Membentuk Matriks keputusan

Membangun sebuah Matriks Keputusan Matriks keputusan X mengacu terhadap m alternatif yang akan dievaluasi berdasarkan $\mathrm{n}$ kriteria. Matriks keputusan $X$ dapat dilihat sebagai berikut [10].

$$
x=\begin{gathered}
a_{1} \\
a_{2} \\
a_{3} \\
\vdots \\
\vdots \\
a_{m}
\end{gathered}\left[\begin{array}{cccccc}
X_{11} & X_{12} & X_{13} & \ldots & \ldots & X_{1 m} \\
X_{21} & X_{22} & X_{23} & \ldots & \ldots & X_{2 m} \\
X_{31} & X_{32} & X_{33} & \ldots & \ldots & X_{3 m} \\
\vdots & \vdots & \vdots & \vdots & \vdots & \vdots \\
\vdots & \ldots & \vdots & \vdots & \vdots & \vdots \\
X_{m 1} & X_{m 2} & X_{m 3} & \ldots & \ldots & X_{m n}
\end{array}\right]
$$

2. Menentukan Matriks keputusan yang ternormalisasi (R)

$$
x=\frac{x_{i j}}{\sqrt{\sum_{j=1}^{m} x_{i j}}} \quad \mathrm{i}=1,2, \ldots, \mathrm{n} ; \mathrm{j}=1,2, \ldots, \mathrm{m}
$$

Dimana:

$\mathrm{xij}=$ rating kinerja alternatif ke-i terhadap atribut ke-j

rij = elemen dari matriks keputusann yang ternormalisasi

3. Menghitung matriks $\mathrm{Y}$

$$
Y_{i j}=w_{i} r_{i j} \quad \text { dengan } \mathrm{i}=1,2, \ldots, \mathrm{n}
$$

4. Mencari solusi ideal positif (A+) dan solusi ideal negative (A-)

$A+=(y 1+, y 2+, \ldots, y j+)$

$A^{-}=\left(y 1-, y 2-, \ldots, y j^{-}\right)$

dengan

$$
\begin{array}{r}
\mathrm{y}_{j}^{+}=\left\{\begin{array}{lr}
\max _{i} y_{i j} & ; j i k a j \text { adalah atribut keuntungan } \\
\min _{i} y_{i j} & ; j i k a j \text { adalah atribut biaya }
\end{array}\right. \\
\mathrm{y}_{j}=\left\{\begin{array}{lr}
\min _{i} y_{i j} & ; j i k a j \text { adalah atribut keuntungan } \\
\min _{i} y_{i j} & ; j i k a j \text { adalah atribut biaya }
\end{array}\right.
\end{array}
$$

5. Mencari jarak terpendek dan terjauh antara alternatif Ai matrik Y dengan solusi ideal positif dan solusi ideal negative dirumuskan dengan:

$$
\begin{array}{lll}
\mathrm{D}_{i}^{+} & =\sqrt{\sum_{j=1}^{n}\left(y_{i j}-y_{j}^{+}\right)^{2}} \quad ; \quad \text { dengan } \mathrm{i}=1,2, \ldots, \mathrm{m} \\
\mathrm{D}_{i}^{-} & =\sqrt{\sum_{j=1}^{n}\left(y_{i j}-y_{j}^{-}\right)^{2}} \quad ; & \text { dengan } \mathrm{i}=1,2, \ldots, \mathrm{m}
\end{array}
$$

6. $\quad$ Manghitung Preferensi

Nilai preferensi untuk setiap alternatif $\left(\mathrm{V}_{\mathrm{i}}\right)$ diberikan dengan:

$$
V_{i}=\frac{D_{i}^{-}}{D_{i}^{-}+D_{i}^{+}} ; \quad \mathrm{i}=1,2, \ldots, \mathrm{m}
$$


Nilai $\mathrm{V}_{\mathrm{i}}$ yang lebih besar menunjukkan bahwa alternatif $\mathrm{A}_{\mathrm{i}}$ lebih terpilih.

\section{HASIL DAN PEMBAHASAN}

\subsection{Penentuan Kriteria dan Bobot}

Dalam perancangan sistem pendukung keputusan untuk menentukan pihak-pihak yang berhak menerima bantuan sosial UMKM menggunakan metode TOPSIS memerlukan kriteria-kriteria dan bobot preferensi untuk mengukur kinerja relative dari alternatif-alternatif keputusan dalam bentuk matematis yang sederhana. Tabel 1 merupakan kriteria, bobot dan jenis dari tiap tiap kriteria yang saling mempengaruhi. Untuk bobot pada tiap kriteria diperoleh dari metode Rank Order Centroid (ROC).

Tabel 1. Daftar Kriteria

\begin{tabular}{lllc}
\hline Kriteria & Kriteria & Atribut & Bobot \\
\hline C1 & Jenis Usaha & Benefit & 0.521 \\
C2 & Kepemilikan Usaha & Benefit & 0.271 \\
C3 & Tanggungan & Benefit & 0.146 \\
C4 & Pendapatan (per hari) & Cost & 0.063 \\
\hline
\end{tabular}

Untuk nilai pada tiap alternatif masih bersifat linguistik, sehingga perlu dilakukan pembobotan sederhana yang dapat dilihat pada tabel 2 .

Tabel 2. Bobot untuk penilaian alternatif

\begin{tabular}{clc}
\hline Kriteria & \multicolumn{1}{c}{ Keterangan } & Nilai Bobot \\
\hline C1 & Menjahit & 6 \\
& Bengkel & 5 \\
& Warung Makan & 4 \\
& Penjual Online & 3 \\
& Membuat Keripik & 2 \\
& Penjual Makanan Ringan & 1 \\
C2 & Pemilik & 2 \\
& Sewa & 1 \\
\hline
\end{tabular}

\subsection{Penetapan Data Alternatif}

Data alternatif yang diuji pada penelitian ini sebanyak 20 data pihak usaha, seperti pada tabel 3.

Tabel 3. Data Bobot Pemohon

\begin{tabular}{clcccc}
\hline No & Alternatif & C1 & C2 & C3 & C4 \\
\hline 1 & Suriana & Penjual Makanan Ringan & Pemilik & 1 orang & 800 per hari \\
2 & Ratmi & Penjual Makanan Ringan & Pemilik & 3 orang & 800 per hari \\
3 & Yani & Penjual Makanan Ringan & Pemilik & 1 orang & 300 per hari \\
4 & Anto & Bengkel & Sewa & 3 orang & 700 per hari \\
5 & Jepri & Penjual Online & Pemilik & 2 orang & 100 per hari \\
6 & Nisa & Penjual Makanan Ringan & Pemilik & 2 orang & 300 per hari \\
7 & Andi & Membuat Keripik & Pemilik & 3 orang & 300 per hari \\
8 & Wiwik & Penjual Online & Sewa & 1 orang & 150 per hari \\
9 & Bawon & Menjahit & Pemilik & 3 orang & 100 per hari \\
10 & Jiri & Membuat Keripik & Sewa & 3 orang & 100 per hari \\
11 & Pian & Penjual Makanan Ringan & Sewa & 3 orang & 100 per hari \\
12 & Irat & Penjual Makanan Ringan & Pemilik & 2 orang & 100 per hari \\
13 & Susi & Menjahit & Sewa & 3 orang & 200 per hari \\
14 & Ani & Penjual Makanan Ringan & Pemilik & 3 orang & 150 per hari \\
15 & Iyem & Penjual Makanan Ringan & Pemilik & 3 orang & 100 per hari \\
16 & Supri & Warung Makan & Sewa & 1 orang & 600 per hari \\
17 & Koling & Bengkel & Pemilik & 2 orang & 700 per hari \\
18 & Faisal & Bengkel & Sewa & 3 orang & 600 per hari \\
19 & Sapri & Membuat Keripik & Sewa & 3 orang & 150 per hari \\
20 & Undel & Warung Makan & Pemilik & 2 orang & 600 per hari \\
\hline
\end{tabular}


Agar data yang terdapat pada tabel 3 bisa diproses, dilakukan proses pembobotan berdasarkan pada tabel 2, sehingga diperoleh data rating kecocokan yang terlihat pada tabel 4 .

Tabel 4. Data Rating Kecocokan

\begin{tabular}{lcccc}
\hline \multicolumn{1}{c}{ Alternatif } & C1 & C2 & C3 & C4 \\
\hline Suriana(A1) & 1 & 2 & 1 & 3 \\
Ratmi (A2) & 1 & 2 & 3 & 3 \\
Yani (A3) & 1 & 2 & 1 & 2 \\
Anto (A4) & 5 & 1 & 3 & 3 \\
Jepri (A5) & 3 & 2 & 2 & 1 \\
Nisa (A6) & 1 & 2 & 2 & 1 \\
Andi (A7) & 2 & 2 & 3 & 2 \\
Wiwik (A8) & 3 & 1 & 1 & 2 \\
Bawon (A9) & 6 & 2 & 3 & 3 \\
Jiri (A10) & 2 & 1 & 3 & 1 \\
Pian (A11) & 1 & 1 & 3 & 2 \\
Irat (A12) & 1 & 2 & 2 & 2 \\
Susi (A13) & 6 & 1 & 3 & 3 \\
Ani (A14) & 1 & 2 & 3 & 2 \\
Iyem (A15) & 1 & 2 & 3 & 1 \\
Supri (A16) & 4 & 1 & 1 & 3 \\
Koling (A17) & 5 & 2 & 2 & 3 \\
Faisal (A18) & 5 & 1 & 3 & 3 \\
Sapri (A19) & 2 & 1 & 3 & 2 \\
Undel (A20) & 4 & 2 & 2 & 2 \\
\hline
\end{tabular}

\subsection{Penerapan Metode TOPSIS}

Terdapat beberapa langkah untuk mendapatkan rangking pada metode TOPSIS, langkah yang pertama yaitu membentuk matriks keputusan.

$$
\mathrm{Xij}=\left|\begin{array}{cccc}
1 & 2 & 1 & 3 \\
1 & 2 & 3 & 3 \\
1 & 2 & 1 & 2 \\
5 & 1 & 3 & 3 \\
3 & 2 & 2 & 1 \\
1 & 2 & 2 & 1 \\
2 & 2 & 3 & 2 \\
3 & 1 & 1 & 2 \\
6 & 2 & 3 & 3 \\
2 & 1 & 3 & 1 \\
1 & 1 & 3 & 2 \\
1 & 2 & 2 & 2 \\
6 & 1 & 3 & 3 \\
1 & 2 & 3 & 2 \\
1 & 2 & 3 & 1 \\
4 & 1 & 1 & 3 \\
5 & 2 & 2 & 3 \\
5 & 1 & 3 & 3 \\
2 & 1 & 3 & 2 \\
4 & 2 & 2 & 2
\end{array}\right|
$$

Langkah kedua yaitu normalisasi dengan mengkuadratkan tiap nilai dengan menggunakan rumus persamaan (1).

$\left|X_{1}\right|=\sqrt{1^{2}+1^{2}+1^{2}+5^{2}+3^{2}+1^{2}+2^{2}+3^{2}+6^{2}+2^{2}+1^{2}+1^{2}+6^{2}+1^{2}+1^{2}+4^{2}+5^{2}}$
$+5^{2}+2^{2}+4^{2}$

$R_{11}=\frac{X_{11}}{\left|X_{1}\right|}=\frac{1}{14.730}=14.730$ 


$$
\begin{aligned}
& R_{21}=\frac{X_{21}}{\left|X_{1}\right|}=\frac{1}{14.730}=14.730 \\
& R_{31}=\frac{X_{31}}{\left|X_{1}\right|}=\frac{1}{14.730}=14.730 \\
& R_{41}=\frac{X_{41}}{\left|X_{1}\right|}=\frac{5}{14.730}=2.946 \\
& R_{51}=\frac{X_{51}}{\left|X_{1}\right|}=\frac{3}{14.730}=4.910 \\
& R_{61}=\frac{X_{61}}{\left|X_{1}\right|}=\frac{1}{14.730}=14.730 \\
& R_{71}=\frac{X_{71}}{\left|X_{1}\right|}=\frac{2}{14.730}=7.365 \\
& R_{81}=\frac{X_{81}}{\left|X_{1}\right|}=\frac{3}{14.730}=4.910
\end{aligned}
$$

Lakukan sampai semua proses sehingga akan membentuk matrik $\mathrm{R}$, seperti berikut ini:

$\mathrm{R}=\left|\begin{array}{cccc}14.730 & 3.741 & 10.723 & 2.603 \\ 14.730 & 3.741 & 3.574 & 2.603 \\ 14.730 & 3.741 & 10.723 & 7.810 \\ 2.946 & 7.483 & 3.574 & 2.603 \\ 4.910 & 3.741 & 5.361 & 7.810 \\ 14.730 & 3.741 & 5.361 & 7.810 \\ 7.365 & 3.741 & 10.723 & 7.810 \\ 4.910 & 7.483 & 10.723 & 7.810 \\ 2.455 & 3.741 & 3.574 & 7.810 \\ 7.365 & 7.483 & 3.574 & 7.810 \\ 14.730 & 7.483 & 3.574 & 7.810 \\ 14.730 & 3.741 & 5.361 & 7.810 \\ 2.455 & 7.483 & 3.574 & 7.810 \\ 14.730 & 3.741 & 3.574 & 7.810 \\ 14.730 & 3.741 & 3.574 & 7.810 \\ 3.682 & 7.483 & 10.723 & 3.905 \\ 2.946 & 3.741 & 5.361 & 2.603 \\ 2.946 & 7.483 & 3.574 & 3.905 \\ 7.365 & 7.483 & 3.574 & 7.810 \\ 3.682 & 3.741 & 5.361 & 3.905\end{array}\right|$

Langkah yang ketiga menghitung matrik Y, seperti persamaan 2.

$\mathrm{Y}_{11}=W_{1} r_{11}=(0.521)(14.730)=7.674$

$\mathrm{Y}_{12}=W_{2} r_{12}=(0.271)(3.741)=1.013$

$\mathrm{Y}_{13}=W_{3} r_{13}=(0.146)(10.723)=1.565$

$Y_{14}=W_{4} r_{14}=(0.063)(2.603)=0.164$

Lakukan sampai semua proses dilakukan sehingga menghasilkan matrik Y, seperti berikut ini:

$\mathrm{Y}=\left|\begin{array}{llll}7.674 & 1.013 & 1.565 & 0.164 \\ 7.674 & 1.013 & 0.521 & 0.164 \\ 7.674 & 1.013 & 1.565 & 0.492 \\ 1.534 & 2.027 & 0.521 & 0.164 \\ 2.558 & 1.013 & 0.782 & 0.492 \\ 7.674 & 1.013 & 0.782 & 0.492 \\ 3.837 & 1.013 & 1.565 & 0.492 \\ 2.558 & 2.027 & 1.565 & 0.492 \\ 1.279 & 1.013 & 0.521 & 0.492 \\ 3.837 & 2.027 & 0.521 & 0.492 \\ 7.674 & 2.027 & 0.521 & 0.492 \\ 7.674 & 1.013 & 0.782 & 0.492 \\ 1.279 & 2.027 & 0.521 & 0.492 \\ 7.674 & 1.013 & 0.521 & 0.492\end{array}\right|$




$\begin{array}{llll}7.674 & 1.013 & 0.521 & 0.492 \\ 1.918 & 2.027 & 1.565 & 0.246 \\ 1.534 & 1.013 & 0.782 & 0.164 \\ 1.534 & 2.027 & 0.521 & 0.246 \\ 3.837 & 2.027 & 0.521 & 0.492 \\ 1.918 & 1.013 & 0.782 & 0.246\end{array}$

Langkah keempat mencari solusi ideal positif akan menghasilkan nilai tertinggi dari hasil normalisasi terbobot sedangkan solusi ideal negatif akan menghasilkan nilai terendah dari hasil normalisasi terbobot, seperti persamaan 3 dan persamaan 4.

$$
\begin{aligned}
& Y_{1}^{+}=\max \left\{\begin{array}{c}
7.674 ; 7.674 ; 7.674 ; 1.534 ; 2.558 ; 7.674 ; 3.837 ; 2.558 ; 1.279 ; 3.837 ; 7.674 ; 7.674 ; 1.279 ; \\
7.674 ; 7.674 ; 1.918 ; 1.534 ; 1.534 ; 3.837 ; 1.918
\end{array}\right\} \\
& =7.674 \\
& Y_{2}^{+}=\max \left\{\begin{array}{c}
1.013 ; 1.013 ; 1.013 ; 2.027 ; 1.013 ; 1.013 ; 1.013 ; 2.027 ; 1.013 ; 2.027 ; 2.027 ; 1.013 ; 2.027 ; \\
1.013 ; 1.013 ; 2.027 ; 1.013 ; 2.027 ; 2.027 ; 1.013
\end{array}\right\} \\
& =2.027 \\
& Y_{3}^{+}=\max \left\{\begin{array}{c}
1.565 ; 0.521 ; 1.565 ; 0.521 ; 0.782 ; 0.782 ; 1.565 ; 1.565 ; 0.521 ; 0.521 ; 0.521 ; 0.782 ; 0.521 ; \\
0.521 ; 0.521 ; 1.565 ; 0.782 ; 0.521 ; 0.521 ; 0.782
\end{array}\right\} \\
& =1.565 \\
& Y_{4}^{+}=\max \left\{\begin{array}{c}
0.164 ; 0.164 ; 0.492 ; 0.164 ; 0.492 ; 0.492 ; 0.492 ; 0.492 ; 0.492 ; 0.492 ; 0.492 ; 0.492 ; 0.492 ; \\
0.492 ; 0.492 ; 0.246 ; 0.164 ; 0.246 ; 0.492 ; 0.246
\end{array}\right\} \\
& =0.492
\end{aligned}
$$

$A^{+}=\max \{7.674 ; 2.027 ; 1.565 ; 0.492\}$

Solusi Ideal Negatif dengan menggunakan persamaan 4

$$
\begin{aligned}
& Y_{1}^{-}=\min \{7.674 ; 7.674 ; 7.674 ; 1.534 ; 2.558 ; 7.674 ; 3.837 ; 2.558 ; 1.279 ; 3.837 ; 7.674 ; 7.674 ; 1.279 ;\} \\
& =1.279 \\
& Y_{2}^{-}=\min \left\{\begin{array}{c}
1.013 ; 1.013 ; 1.013 ; 2.027 ; 1.013 ; 1.013 ; 1.013 ; 2.027 ; 1.013 ; 2.027 ; 2.027 ; 1.013 ; 2.027 ; \\
1.013 ; 1.013 ; 2.027 ; 1.013 ; 2.027 ; 2.027 ; 1.013
\end{array}\right\} \\
& =1.031 \\
& Y_{3}^{-}=\min \left\{\begin{array}{c}
1.565 ; 0.521 ; 1.565 ; 0.521 ; 0.782 ; 0.782 ; 1.565 ; 1.565 ; 0.521 ; 0.521 ; 0.521 ; 0.782 ; 0.521 ; \\
0.521 ; 0.521 ; 1.565 ; 0.782 ; 0.521 ; 0.521 ; 0.782
\end{array}\right\} \\
& =0.521 \\
& Y_{4}^{-}=\min \left\{\begin{array}{c}
0.164 ; 0.164 ; 0.492 ; 0.164 ; 0.492 ; 0.492 ; 0.492 ; 0.492 ; 0.492 ; 0.492 ; 0.492 ; 0.492 ; 0.492 ; \\
0.492 ; 0.492 ; 0.246 ; 0.164 ; 0.246 ; 0.492 ; 0.246
\end{array}\right\} \\
& =0.164
\end{aligned}
$$

$A^{-}=\min \{1.279 ; 1.031 ; 0.521 ; 0.164\}$

Langkah kelima mencari hasil jarak solusi ideal positif dan negatif menggunakan persamaan 5 dan 6

$D_{1}^{+}=\sqrt{(7.674-7.674)^{2}+(1.013-2.027)^{2}+(1.565-1.565)^{2}+(0.164-0.492)^{2}}=1.065$

$D_{2}^{+}=\sqrt{(7.674-7.674)^{2}+(1.013-2.027)^{2}+(0.521-1.565)^{2}+(0.164-0.492)^{2}}=1.491$

$D_{3}^{+}=\sqrt{(7.674-7.674)^{2}+(1.013-2.027)^{2}+(1.565-1.565)^{2}+(0.492-0.492)^{2}}=1.013$

$D_{4}^{+}=\sqrt{(1.534-7.674)^{2}+(2.027-2.027)^{2}+(0.521-1.565)^{2}+(0.164-0.492)^{2}}=6.236$

$D_{5}^{+}=\sqrt{(2.558-7.674)^{2}+(1.013-2.027)^{2}+(0.782-1.565)^{2}+(0.492-0.492)^{2}}=5.274$

$D_{6}^{+}=\sqrt{(7.674-7.674)^{2}+(1.013-2.027)^{2}+(0.782-1.565)^{2}+(0.492-0.492)^{2}}=1.281$

$D_{7}^{+}=\sqrt{(3.837-7.674)^{2}+(1.013-2.027)^{2}+(1.565-1.565)^{2}+(0.492-0.492)^{2}}=3.969$

$D_{8}^{+}=\sqrt{(2.558-7.674)^{2}+(2.027-2.027)^{2}+(1.565-1.565)^{2}+(0.492-0.492)^{2}}=5.116$

$D_{9}^{+}=\sqrt{(1.279-7.674)^{2}+(1.013-2.027)^{2}+(0.521-1.565)^{2}+(0.492-0.492)^{2}}=6.559$

$D_{10}^{+}=\sqrt{(3.837-7.674)^{2}+(2.027-2.027)^{2}+(0.521-1.565)^{2}+(0.492-0.492)^{2}}=3.976$

$D_{11}^{+}=\sqrt{(7.674-7.674)^{2}+(2.027-2.027)^{2}+(0.521-1.565)^{2}+(0.492-0.492)^{2}}=1.043$

$D_{12}^{+}=\sqrt{(7.674-7.674)^{2}+(1.013-2.027)^{2}+(0.782-1.565)^{2}+(0.492-0.492)^{2}}=1.281$

$D_{13}^{+}=\sqrt{(1.279-7.674)^{2}+(2.027-2.027)^{2}+(0.521-1.565)^{2}+(0.492-0.492)^{2}}=6.480$

$D_{14}^{+}=\sqrt{(7.674-7.674)^{2}+(1.013-2.027)^{2}+(0.521-1.565)^{2}+(0.492-0.492)^{2}}=1.455$

$D_{15}^{+}=\sqrt{(7.674-7.674)^{2}+(1.013-2.027)^{2}+(0.521-1.565)^{2}+(0.492-0.492)^{2}}=1.455$

$D_{16}^{+}=\sqrt{(1.918-7.674)^{2}+(2.027-2.027)^{2}+(1.565-1.565)^{2}+(0.246-0.492)^{2}}=5.761$

$D_{17}^{+}=\sqrt{(1.534-7.674)^{2}+(1.013-2.027)^{2}+(0.782-1.565)^{2}+(0.164-0.492)^{2}}=6.280$ 


$$
\begin{aligned}
& D_{18}^{+}=\sqrt{(1.534-7.674)^{2}+(2.027-2.027)^{2}+(0.521-1.565)^{2}+(0.246-0.492)^{2}}=6.232 \\
& D_{19}^{+}=\sqrt{(3.837-7.674)^{2}+(2.027-2.027)^{2}+(0.521-1.565)^{2}+(0.492-0.492)^{2}}=3.976 \\
& D_{20}^{+}=\sqrt{(1.918-7.674)^{2}+(1.013-2.027)^{2}+(0.782-1.565)^{2}+(0.246-0.492)^{2}}=5.902
\end{aligned}
$$

Solusi Ideal Negatif dengan menggunakan persamaan 4

$D_{1}^{-}=\sqrt{(7.674-1.279)^{2}+(1.013-1.013)^{2}+(1.565-0.521)^{2}+(0.164-0.164)^{2}}=6.480$
$D_{2}^{-}=\sqrt{(7.674-1.279)^{2}+(1.013-1.013)^{2}+(0.521-0.521)^{2}+(0.164-0.164)^{2}}=6.305$
$D_{3}^{-}=\sqrt{(7.674-1.279)^{2}+(1.013-1.013)^{2}+(1.565-0.521)^{2}+(0.492-0.164)^{2}}=6.488$
$D_{4}^{-}=\sqrt{(1.534-1.279)^{2}+(2.027-1.013)^{2}+(0.521-0.521)^{2}+(0.164-0.164)^{2}}=1.045$
$D_{5}^{-}=\sqrt{(2.558-1.279)^{2}+(1.013-1.013)^{2}+(0.782-0.521)^{2}+(0.492-0.164)^{2}}=1.346$
$D_{6}^{-}=\sqrt{(7.674-1.279)^{2}+(1.013-1.013)^{2}+(0.782-0.521)^{2}+(0.492-0.164)^{2}}=6.409$
$D_{7}^{-}=\sqrt{(3.837-1.279)^{2}+(1.013-1.013)^{2}+(1.565-0.521)^{2}+(0.492-0.164)^{2}}=2.782$
$D_{8}^{-}=\sqrt{(2.558-1.279)^{2}+(2.027-1.013)^{2}+(1.565-0.521)^{2}+(0.492-0.164)^{2}}=1.965$
$D_{9}^{-}=\sqrt{(1.279-1.279)^{2}+(1.013-1.013)^{2}+(0.521-0.521)^{2}+(0.492-0.164)^{2}}=0.328$
$D_{10}^{-}=\sqrt{(3.837-1.279)^{2}+(2.027-1.013)^{2}+(0.521-0.521)^{2}+(0.492-0.164)^{2}}=2.771$
$D_{11}^{-}=\sqrt{(7.674-1.279)^{2}+(2.027-1.013)^{2}+(0.521-0.521)^{2}+(0.492-0.164)^{2}}=6.483$
$D_{12}^{-}=\sqrt{(7.674-1.279)^{2}+(1.013-1.013)^{2}+(0.782-0.521)^{2}+(0.492-0.164)^{2}}=6.409$
$D_{13}^{-}=\sqrt{(1.279-1.279)^{2}+(2.027-1.013)^{2}+(0.521-0.521)^{2}+(0.492-0.164)^{2}}=1.065$
$D_{14}^{-}=\sqrt{(7.674-1.279)^{2}+(1.013-1.013)^{2}+(0.521-0.521)^{2}+(0.492-0.164)^{2}}=6.404$
$D_{15}^{-}=\sqrt{(7.674-1.279)^{2}+(1.013-1.013)^{2}+(0.521-0.521)^{2}+(0.492-0.164)^{2}}=6.404$
$D_{16}^{-}=\sqrt{(1.918-1.279)^{2}+(2.027-1.013)^{2}+(1.565-0.521)^{2}+(0.246-0.164)^{2}}=1.591$
$D_{17}^{-}=\sqrt{(1.534-1.279)^{2}+(1.013-1.013)^{2}+(0.782-0.521)^{2}+(0.164-0.164)^{2}}=0.365$
$D_{18}^{-}=\sqrt{(1.534-1.279)^{2}+(2.027-1.013)^{2}+(0.521-0.521)^{2}+(0.246-0.164)^{2}}=1.048$
$D_{19}^{-}=\sqrt{(3.837-1.279)^{2}+(2.027-1.013)^{2}+(0.521-0.521)^{2}+(0.492-0.164)^{2}}=2.771$
$D_{20}^{-}=\sqrt{(1.918-1.279)^{2}+(1.013-1.013)^{2}+(0.782-0.521)^{2}+(0.246-0.164)^{2}}=0.695$

Langkah keenam menghitung preferensi $\left(C_{i}\right)$ untuk setiap alternatif, seperti persamaan 7 .

$C_{1}=\frac{6.480}{6.480+1.065}=0.858$

$C_{2}=\frac{6.305}{6.305+1.491}=0.810$

$C_{3}=\frac{6.488}{6.488+1.013}=0.864$

$C_{4}=\frac{1.045}{1.045+6.236}=0.143$

$C_{5}=\frac{1.346}{1.346+5.274}=0.203$

Lakukan sampai semua proses dilakukan sehingga didapatkan dalam menetapkan peringkat dari hasil perhitungan metode TOPSIS dari hasil preferensi seperti tabel 5.

Tabel 5. Laporan Peringkat Alternatif

\begin{tabular}{cccccc}
\hline No & Alternatif & $\begin{array}{c}\text { Nama } \\
\text { Pemohon }\end{array}$ & Preferensi & Ranking & Status \\
\hline 1 & A3 & Yani & 0.864 & 1 & Berhak Mendapat Bantuan \\
2 & A11 & Pian & 0.861 & 2 & Berhak Mendapat Bantuan \\
3 & A1 & Suriana & 0.858 & 3 & Berhak Mendapat Bantuan \\
4 & A6 & Nisa & 0.833 & 4 & Berhak Mendapat Bantuan \\
5 & A12 & Irat & 0.833 & 5 & Berhak Mendapat Bantuan \\
6 & A14 & Ani & 0.814 & 6 & Berhak Mendapat Bantuan
\end{tabular}




\begin{tabular}{cccccc}
\hline 7 & A15 & Iyem & 0.814 & 7 & Berhak Mendapat Bantuan \\
8 & A2 & Ratmi & 0.810 & 8 & Berhak Mendapat Bantuan \\
9 & A7 & Andi & 0.412 & 9 & Tidak Berhak Mendapat Bantuan \\
10 & A10 & Jiri & 0.410 & 10 & Tidak Berhak Mendapat Bantuan \\
11 & A19 & Sapri & 0.410 & 11 & Tidak Berhak Mendapat Bantuan \\
12 & A8 & Wiwik & 0.277 & 12 & Tidak Berhak Mendapat Bantuan \\
13 & A16 & Supri & 0.216 & 13 & Tidak Berhak Mendapat Bantuan \\
14 & A5 & Jepri & 0.203 & 14 & Tidak Berhak Mendapat Bantuan \\
15 & A18 & Faisal & 0.144 & 15 & Tidak Berhak Mendapat Bantuan \\
16 & A4 & Anto & 0.143 & 16 & Tidak Berhak Mendapat Bantuan \\
17 & A13 & Susi & 0.141 & 17 & Tidak Berhak Mendapat Bantuan \\
18 & A20 & Undel & 0.105 & 18 & Tidak Berhak Mendapat Bantuan \\
19 & A17 & Koling & 0.054 & 19 & Tidak Berhak Mendapat Bantuan \\
20 & A9 & Bawon & 0.047 & 20 & Tidak Berhak Mendapat Bantuan \\
\hline
\end{tabular}

Bedasarkan hasil penerapan metode TOPSIS dalam prmngambilan keputusan penerimaan bantuan sosial UMKM yang yang berhak menerima bantuan apabila nilai preferensinya melebihi 0.5 jadi apabila nilai preferensi yang dihasilkan oleh tiap pemohon kurang dari 0.5 maka akan menampilkan tidak berhak menerima bantuan.

\section{KESIMPULAN}

Hasil penelitian dan pembahasan pada sistem pendukung keputusan penerimaan bantuan sosial UMKM menggunakan metode TOPSIS, dapat disimpulkan bahwa hasil pengujian sistem dengan melakukan proses penyeleksian terhadap data pemohon yang telah diinputkan berdasarkan beberapa kriteria. Adapun kriteria yang digunakan untuk penyeleksian pihak usaha yaitu: Jenis Usaha, Kepemilikan Usaha, Tanggungan, dan Penghasilan. Sistem akan menampilkan siapa saja yang berhak menerima bantuan apabila nilai preferensinya melebihi 0.5 jadi apabila nilai preferensi yang dihasilkan oleh tiap pemohon kurang dari 0.5 maka akan menampilkan tidak berhak menerima bantuan. Hasil dari pembahasan sistem pendukung keputusan penerimaan bantuan sosial UMKM menggunakan metode TOPSIS berdasarkan kriteria-kriteria yang sudah ditentukan terdapat 8 pemohon yang berhak mendapat bantuan dan 12 orang yang tidak berhak mendapatkan bantuan.

\section{REFERENCES}

[1] Y. Fernando and S. Fernanda, "Penerapan Sistem Pendukung Keputusan Penerimaan Dana Bantuan Operasional Sekolah Pada Siswa Sma N 1 Sidomulyo Menggunakan Metode Topsis Berbasis Web," J. Tekno Kompak, vol. 11, no. 1, p. 29, 2017, doi: 10.33365/jtk.v11i1.181.

[2] M. Arhami and A. Desiani, "Penggunaan Metode TOPSIS sebagai Pendukung Keputusan Bantuan Modal Usaha bagi Masyarakat Pedesaan di Kabupaten Pidie," J. Infomedia Tek. Inform., vol. 5, no. 2, pp. 24-31, 2020.

[3] N. Sudarsono, T. Nuraen, and S. Rahmawati, "Sistem Penunjang Keputusan Pemberian Bantuan Siswa Miskin di SD Negeri Sukamenak Kota Tasikmalaya Menggunakan Metode Technique for Order Preference by Similarity to Ideal Solution (TOPSIS)," Semin. Nas. Teknol. Inf. Dan Multimed., vol. 4, no. 1, pp. 163-168, 2016, [Online]. Available: http://ojs.amikom.ac.id/index.php/semnasteknomedia/article/view/1195.

[4] A. O. Riyandi, N. Dengen, and Islamiyah, "Sistem Pendukung Keputusan Kelayakan Pemberian Bantuan Dana atau Kredit Untuk Usaha Kecil Menengah (UKM) pada Bank Negara Indonesia (BNI),” Pros. SAKTI (Seminar Ilmu Komput. dan Teknol. Informasi), vol. 2, no. 1, pp. 8-13, 2017, [Online]. Available: http://ejournals.unmul.ac.id/index.php/SAKTI/article/view/230.

[5] B. T. S. Hutagalung Elida Tuti; Lubis, Juanda Hakim, "Penerapan Metode SMART dalam Seleksi Penerima Bantuan Sosial Warga Masyarakat Terdampak COVID-19," J. Media Inform. Budidarma, vol. 5, no. Vol 5, No 1 (2021): MIB Januari 2021, pp. 170-185, 2021, doi: 10.30865/mib.v5i1.2618.

[6] D. Apriliani, I. D. Jayanti, and N. Renaningtias, "Implementasi Metode Ahp-Topsis Dalam Sistem Pendukung Keputusan Penentuan Prioritas Bantuan Usaha Kecil Dan Menengah Di Kota Tegal," Indones. J. Technol. Informatics Sci., vol. 2, no. 1, pp. 5-11, 2020, doi: 10.24176/ijtis.v2i1.5603.

[7] O. Nurdiawan, "Seleksi Penerima Bantuan Sosial Berdasarkan Sistem Pendukung Keputusan Dalam Upaya Mengurangi Siswa Rawan Putus Sekolah,” J. Teknol. Inf., vol. XIII, no. 2, pp. 32-40, 2018.

[8] E. J. G. Harianja and G. Lumbantoruan, "Penerapan Metode TOPSIS dalam Menentukan Penerima Bantuan Bedah Rumah Pada Dinas Perumahan Dan Kawasan Permukiman Kabupaten Deli Serdang,” J. Times, vol. 8, no. 1, pp. 2938, 2019.

[9] I. Muzakkir, "Penerapan Metode Topsis Untuk Sistem Pendukung Keputusan Penentuan Keluarga Miskin Pada Desa 
Panca Karsa Ii," Ilk. J. Ilm., vol. 9, no. 3, pp. 274-281, 2017, doi: 10.33096/ilkom.v9i3.156.274-281.

[10] A. Muis, "Implementasi Algoritma Topsis Untuk Sistem Pendukung Keputusan Distribusi Bantuan Kelompok Tani," PROtek J. Ilm. Tek. Elektro, vol. 6, no. 2, pp. 79-84, 2019, doi: 10.33387/protk.v6i2.1231. 